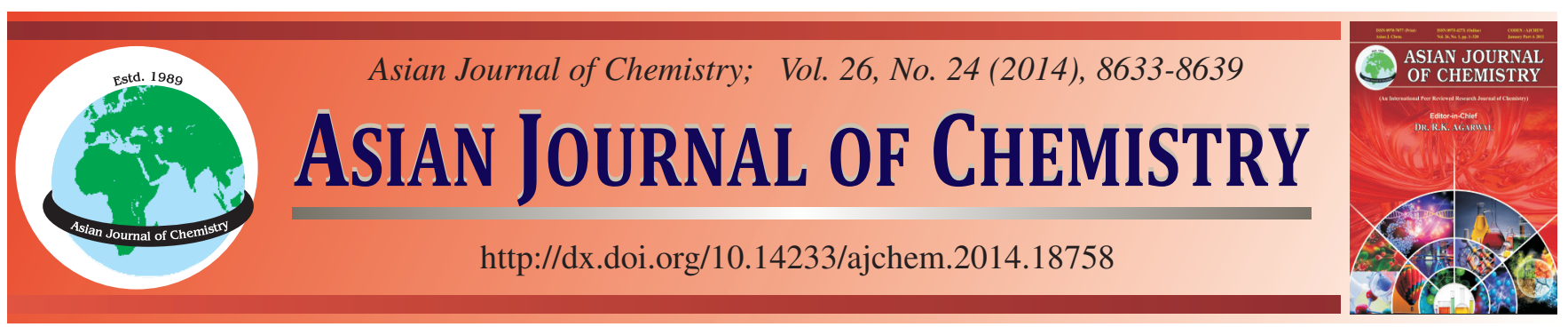

\title{
Sensitive Extractive Spectrophotometric Methods for Determination of Trovafloxacin Mesylate Using Bromothymol Blue and Eriochrome Black-T
}

\author{
Nawal A. Alarfaj ${ }^{1, *}$ and Maha F. El-Tohamy ${ }^{1,2}$
}

${ }^{1}$ Department of Chemistry, College of Science, King Saud University, P.O. Box 22452, Riyadh 11495, Saudi Arabia

${ }^{2}$ General Administrative of Medical Affairs, Zagazig University, Zagazig, Egypt

*Corresponding author: Tel/Fax: +966 14772245; E-mail: nalarfaj@ hotmail.com

\begin{abstract}
Two sensitive and selective extractive spectrophotometric methods have been developed for determination of trovafloxacin mesylate either in pure form or its pharmaceutical dosage forms as well as biological fluids. The developed methods are based on the reaction of the drug with bromothymol blue (method I) and eriochrome black-T (method II) in acidic medium. The formed ion-pair coloured complexes at $\mathrm{pH} 3.5$ and 3.8 were extracted quantitatively using chloroform and the absorbance maxima of the organic layer were measured at $\lambda_{\max }$ 415 and $530 \mathrm{~nm}$ for methods I and II, respectively. Beer's law was obeyed under optimum experimental conditions and revealed that the linear concentration ranges were 2-100 and 5-130 $\mu \mathrm{g} \mathrm{mL}^{-1}$ with bromothymol blue and eriochrome-black T, respectively. The correlation coefficients were $(r=0.9991$ and 0.9993$)$ with lower detection limits 0.87 and $1.84 \mu \mathrm{g} \mathrm{mL}^{-1}$ and quantification limits 2 and $5 \mu \mathrm{g} \mathrm{mL}{ }^{-1}$ for both methods, respectively. The proposed methods have been successfully applied for determination of trovafloxacin mesylate in pharmaceutical formulations and biological fluids. The interference of some common pharmaceutical additives was investigated and no interference was observed. The reliability and the performance of the proposed methods were validated according to ICH guidelines and the obtained results were statistically treated and compared with those obtained from a reported method.
\end{abstract}

Keywords: Trovafloxacin mesylate, Extractive spectrophotometry, Bromothymol blue, Eriochrome black-T, Biological fluids.

\section{INTRODUCTION}

Bromothymol blue (BTB, Fig. 1a), 4,4'-(1,1-dioxido3H-2,1-benzoxathiole-3,3-diyl) bis (2-bromo-6-isopropyl3-methyl-phenol) is a commonly $\mathrm{pH}$ sensitive dye that has been used as an indicator in many analytical reactions ${ }^{1}$. The literature survey clarified that several methods have been reported for determination of many drugs by ion pair complex formation with bromothymol blue such as ketoconazole, clotrimazole and fluconazole ${ }^{2}$, antiallergic drugs ${ }^{3}$, diltiazem hydrochloride ${ }^{4}$, anti-parkinsonian drug amantadine ${ }^{5}$, gabapentin $^{6}$, nicardipine ${ }^{7}$, rupatadine fumarate $^{8}$, ketotifen $^{9}$ and mirtazapine ${ }^{10}$.

Eriochrome black-T (EBT), is chemically known as 3hydroxy-4-[1-hydroxy-2-naphthalenyl)azo]-nitro-1-naphthylene sulfonic acid mono sodium salt (Fig. 1b). It is a complexometric indicator which commonly used in complexometric titrations. Several methods have been reported for determination of metals such as nickel ${ }^{11}$, calcium $^{12}$, magnesium, zinc, cadmium and copper ${ }^{13}$. Also, eriochrome black-T was used for determination of nucleic acid ${ }^{14}$, pharmaceutical species such as ribavirin $^{15}$, gatifloxacin mesylate ${ }^{16}$, antihypertensive drug nifedipine ${ }^{17}$, antispasmodic drug drotaverine ${ }^{18}$ and epinephrine ${ }^{19}$.

Trovafloxacin (TRX), Fig. 1c, is a synthetic broad-spectrum antibacterial agent used to treat serious infections including pneumonia, complicated abdominal infections, gynecologic and pelvic infections. It is also used in the treatment of skin infections ${ }^{20}$. It is chemically known as $(1 \alpha, 5 \alpha, 6 \alpha)-7-(6$-amino3-azabicyclo[3.1.0]hex-3-yl)-1-(2,4-difluorophenyl)-6-fluoro1,4-dihydro-4-oxo-1,8-naphthyridine-3-carboxylic acid, monomethane sulfonate. Few analytical techniques were reported for determination of trovafloxacin in its pharmaceutical formulations and biological fluids. These include high performance liquid chromatography ${ }^{21-25}$, chemiluminescence ${ }^{26}$, voltammetry $^{27}$, spectrofluorimetry ${ }^{28,29}$ and capillary zone electrophoresis ${ }^{30}$.

In the present study, simple and accurate spectrophotometric methods are developed for determination of trovafloxacin mesylate. The developed methods involve the formation of coloured chloroform extractable ion-pair complexes of the drug with bromothymol blue and eriochrome black-T in acidic medium. The developed methods will employed for determination of the investigated drug in pure 
<smiles>CC1=C(Br)C(=O)C(C(C)C)=C/C1=C(/c1ccccc1S(=O)(=O)O[Na])c1cc(C(C)C)c(O)c(Br)c1C</smiles>

(a)<smiles>O=[N+]([O-])c1ccc2c(/N=N\c3ccc4ccccc4c3O)c(O)cc(S(=O)(=O)O[Na])c2c1</smiles>

(b)

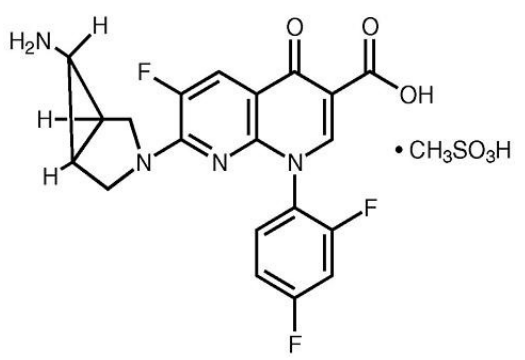

(c)

Fig. 1. Chemical structures of (a) bromothymol blue, (b) eriochrome black-T and (c) trovafloxacin mesylate

bulk powder, dosage forms and biological fluids such as human urine and serum.

\section{EXPERIMENTAL}

All chemicals and reagents were of analytical grade and distilled water was used throughout the experimental procedures. Pure grade of trovafloxacin and its pharmaceutical dosage forms (Trovan ${ }^{\circledR} 100 \mathrm{mg} /$ tablet) were supplied from Pfizer Co. Egypt. Anhydrous sodium sulfate, acetic acid (purity $99.7 \%$ ) and sodium acetate were purchased from SigmaAldrich (Germany). Chloroform (purity $99 \%$ ), benzene (purity $99 \%$ ), methanol (purity $99.8 \%$ ), diethyl ether (purity $99.7 \%$ ) and dichloromethane (purity $99.9 \%$ ) were purchased from BDH laboratory supplies (England). Bromothymol blue sodium salt and eriochrome black-T were obtained from fine LTD (India). Urine samples were obtained from healthy volunteers and serum samples (Multi-Serum Normal, Randox Laboratories, UK) were obtained from commercial sources.

Ultrospec-2100 pro, ultra-visible spectrophotometer with matched $1 \mathrm{~cm}$ quartz cells was used for all spectrophotometric measurements. Shimadzu recording spectrophotometer UV 1201 equipped with $10 \mathrm{~mm}$ matched quartz cells. HANNA $\mathrm{pH}$ meter (Romania) was used for $\mathrm{pH}$ adjustments.

Standard drug solution: Stock solution of trovafloxacin mesylate was prepared by dissolving $10 \mathrm{mg}$ of the drug in 100 $\mathrm{mL}$ of methanol: water $(20: 80 \mathrm{v} / \mathrm{v})$. Further dilutions $2.0-150$ $\mu \mathrm{g} \mathrm{mL}{ }^{-1}$ were done with the same solvent. The standard solution was stable for one week when kept in refrigerator.

Standard bromothymol blue and eriochrome black-T solutions: Standard bromothymol blue sodium salt $0.04 \%$ $(\mathrm{w} / \mathrm{v})$ solution was prepared by dissolving $0.04 \mathrm{~g}$ of the dye in $100 \mathrm{~mL}$ distilled water. While, for eriochrome black-T $0.2 \%$ $(\mathrm{w} / \mathrm{v})$ was prepared in $10 \mathrm{~mL}$ methanol then completed to 100 $\mathrm{mL}$ using distilled water.

\section{Procedure for calibration graph}

Method I: Aliquots of trovafloxacin mesylate standard solution (equivalent to $2-100 \mu \mathrm{g} \mathrm{mL}^{-1}$ of the drug) were transferred into a series of $50 \mathrm{~mL}$ separating funnels. $2 \mathrm{~mL}$ of 0.04 $\%$ (w/v) bromothymol blue was added followed by $2 \mathrm{~mL}$ of acetate buffer solution of $\mathrm{pH} 3.5$. The separating funnels were vigorously shaking and the ion pair complex was extracted with $3 \times 3 \mathrm{~mL}$ chloroform. The organic layer was separated and dried over anhydrous sodium sulfate then transferred into a series of $10 \mathrm{~mL}$ volumetric flasks and completed to volume using distilled water. The absorbances were measured against a blank solution treated under the same conditions at $415 \mathrm{~nm}$.

Method II: Aliquots of trovafloxacin mesylate standard solution (equivalent to $5-130 \mu \mathrm{g} \mathrm{mL}^{-1}$ of the drug) were transferred into a series of $50 \mathrm{~mL}$ separating funnels. $1 \mathrm{~mL}$ of $0.2 \%$ (w/v) eriochrome black-T was added followed by $2 \mathrm{~mL}$ of acetate buffer solution of $\mathrm{pH} 3.8$. The separating funnels were vigorously shaking and the ion pair complex was extracted with $3 \times 3 \mathrm{~mL}$ chloroform. The organic layer was separated and dried over anhydrous sodium sulfate and transferred into a series of $10 \mathrm{~mL}$ volumetric flasks. The volumes were completed using distilled water and the absorbances were measured against a blank solution treated similarly at $530 \mathrm{~nm}$.

Stoichiometric studies: To study the stoichiometric relationship of the ion pairs formed from the investigated drug and the reagents, Job's method of continuous variations method $^{31}$ was employed. Master equimolar solutions $1 \times 10^{-5}$ mol L ${ }^{-1}$ of bromothymol blue, eriochrome black-T and trovafloxacin mesylate were prepared in methanol: water (20:80 v/ v). A series of solutions was prepared in which the total volume of the drug and each reagent were kept at $10 \mathrm{~mL}$. The prepared solutions were comprised different complementary proportions $(0: 10,1: 9 \ldots 9: 1,10: 0)$ in $10 \mathrm{~mL}$ volumetric flasks. The absorbances of the resulting solutions were measured at 415 and $530 \mathrm{~nm}$ against a reagent blank treated similarly for both bromothymol blue and eriochrome black-T, respectively.

\section{Analytical applications}

Determination of trovafloxacin mesylate in Trovan ${ }^{\circledR}$ tablets: Not less than ten tablets (Trovan ${ }^{\circledR} 100 \mathrm{mg}$ per tablet) were finally powdered and mixed well. An accurate weight of the powder equivalent to $10 \mathrm{mg}$ of trovafloxacin mesylate was transferred into a $100 \mathrm{~mL}$ volumetric flask, about $20 \mathrm{~mL}$ of methanol was added and the flask was sonicated for $10 \mathrm{~min}$. The solution was diluted to volume with distilled water, mixed and filtered. Serial dilutions covering the working concentration ranges of 2-100 and 5-130 $\mu \mathrm{g} \mathrm{mL}^{-1}$ were transferred into $10 \mathrm{~mL}$ volumetric flasks. Procedure described earlier. was then followed for each reagent. The content of the tablets was calculated using the calibration graph or the corresponding regression equation.

Determination of trovafloxacin mesylate in human urine and serum: The developed extractable spectrophotometric methods were applied for determination of trovafloxacin mesylate in human urine and serum using bromothymol 
blue and eriochrome black-T in acidic medium. About $1 \mathrm{~mL}$ of human serum or $5 \mathrm{~mL}$ of human urine collected from healthy volunteer was spiked with accurately measured trovafloxacin mesylate. Then the spiked solutions were left aside for $5 \mathrm{~min}$. $1 \mathrm{~mL}$ acetonitrile, $0.1 \mathrm{~mL}$ of $\mathrm{NaOH}\left(0.1 \mathrm{~mol} \mathrm{~L}^{-1}\right), 1 \mathrm{~mL}$ of $\mathrm{ZnSO}_{4} \cdot 7 \mathrm{H}_{2} \mathrm{O}(5 \% \mathrm{w} / \mathrm{v})$ were added, where most of the interfering species (mainly proteins) were removed by precipitation $^{32}$. The solutions were centrifuged for $0.5 \mathrm{~h}$ at $3500 \mathrm{rpm}$ and the clear supernatant layer was filtered through $0.2 \mu \mathrm{m}$ Milli-pore filter. Working solutions were then prepared by serial dilution to obtain trovafloxacin mesylate concentration ranges of 2-100 and 5-150 $\mu \mathrm{g} \mathrm{mL}^{-1}$. The procedure in section 2.5 for each method was employed and the absorbance was recorded at 415 and $530 \mathrm{~nm}$ for trovafloxacin complexes with bromothymol blue and eriochrome black-T, respectively.

\section{RESULTS AND DISCUSSION}

Absorption spectra and pH adjustment: To study the effect of acidity on the absorbance spectra of the developed methods, it is noticed that the investigated trovafloxacin mesylate drug is containing amino group in acidic medium undergoes protonation and forms with bromothymol blue and eriochrome black-T a yellow and red ion-pair complexes, respectively. The influence of $\mathrm{pH}$ on the absorption spectra was studied using $0.5-3.0 \mathrm{~mL}$ of acetate buffer at $\mathrm{pH}$ ranges from 2.5-6.0. The calibration plots clarified that the highest absorbance and the most stable reading was obtained in the presence of $2 \mathrm{~mL}$ of acetate buffer at $\mathrm{pH} 3.5$ and 3.8 for trovafloxacin complexes with bromothymol blue and eriochrome black-T, respectively as shown in Figs. 2 and 3.

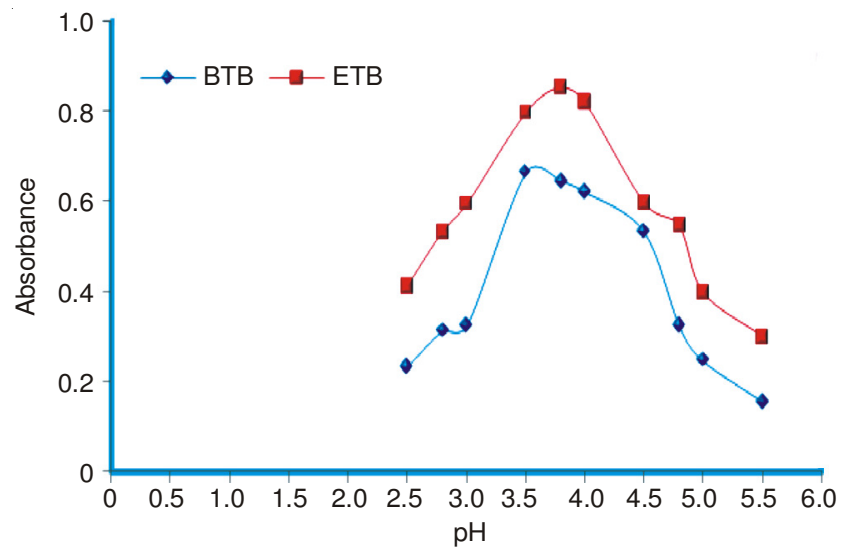

Fig. 2. Effect of $\mathrm{pH}$ of acetate buffer solution on formation of ion-pair complex of trovafloxacin with $0.04 \%$ bromothymol blue and 0.2 $\%$ eriochrome black-T

Effect of bromothymol blue and eriochrome black-T concentrations: Various concentrations ranges (0.01-1.0) \% $(\mathrm{w} / \mathrm{v})$ of each of bromothymol blue and eriochrome black-T were used to investigate their effect on the absorbance of the coloured ion-pair complexes formed by the reaction between the investigated drug with each reagent. The procedure described in 2.5. was followed and the obtained absorbance readings were plotted against bromothymol blue and eriochrome black-T concentrations. The most preferred concentrations were found to be 0.04 and $0.2 \%$ for the previously mentioned reagents, respectively as shown in Fig. 4.

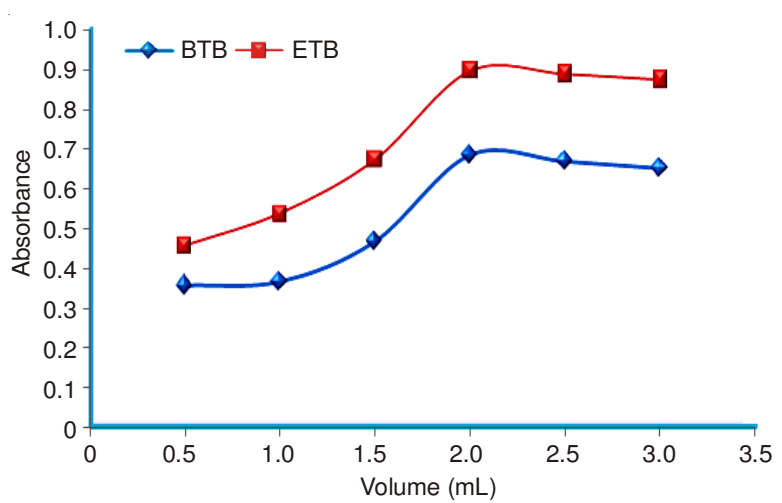

Fig. 3. Effect of volume of acetate buffer solution on ion-pair complex formation absorbance of trovafloxacin with $0.04 \%$ bromothymol blue and $0.2 \%$ eriochrome black-T

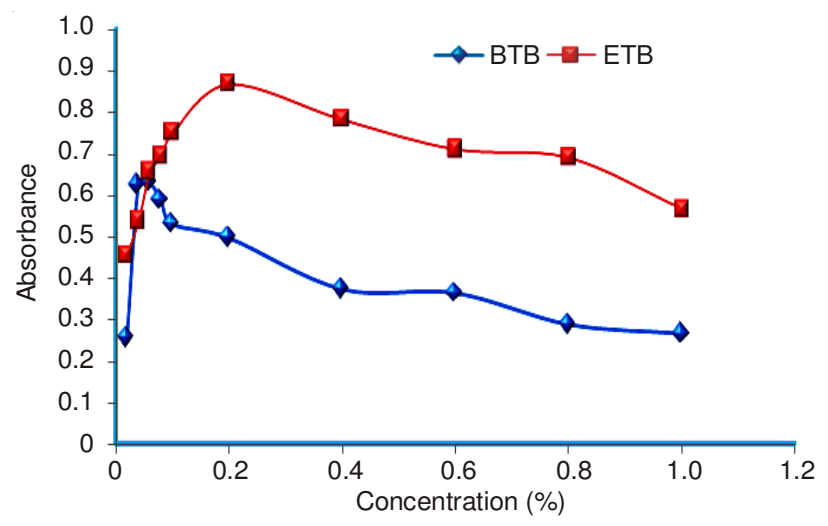

Fig. 4. Effect of concentration of bromothymol blue and eriochrome black$\mathrm{T}$ on ion-pair complex formation absorbance with trovafloxacin

Effect of bromothymol blue and eriochrome black-T volume: The volume of the reagents was carefully studied using various amounts $(0.2-4.0 \mathrm{~mL})$ of $0.04 \%(\mathrm{w} / \mathrm{v})$ bromothymol blue and $0.2 \%(\mathrm{w} / \mathrm{v})$ eriochrome black-T solutions. The procedure described earlier was followed and the obtained absorbance readings were plotted against bromothymol blue and eriochrome black-T volumes. The most preferred volume was found to be 2 and $1 \mathrm{~mL}$ of bromothymol blue and eriochrome black-T, respectively as shown in Fig. 5.

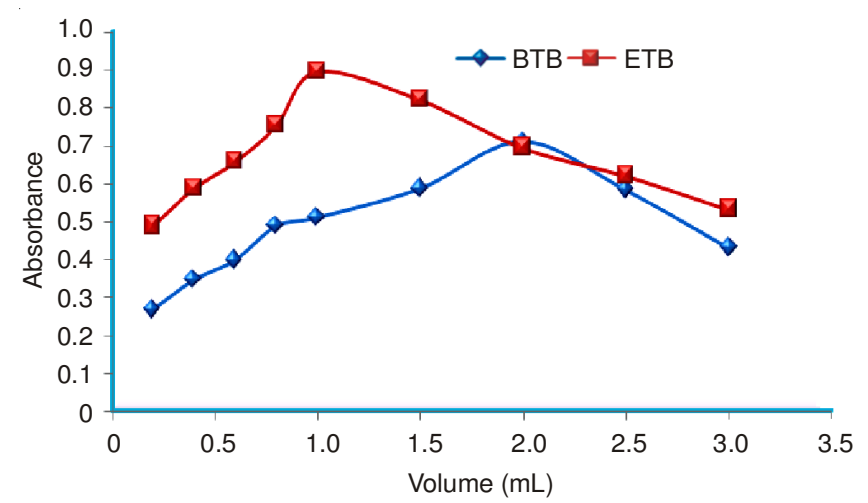

Fig. 5. Effect of volumes of $0.04 \%$ bromothymol blue and $0.2 \%$ eriochrome black-T solution on ion-pair complex formation absorbance with trovafloxacin

Effect of solvent types: The influence of solvent type on the efficiency of extraction and absorbance intensity was investigated by studying various kinds of solvents such as 
(chloroform, dichloromethane, benzene and diethyl ether). The obtained results (Figs. 6 and 7) clarified that chloroform is the appropriate solvent for extraction of the studied drug. It was found that complete extraction was reacted using $3 \times 3$ $\mathrm{mL}$ of chloroform and then complete to $10 \mathrm{~mL}$ with the same solvent.

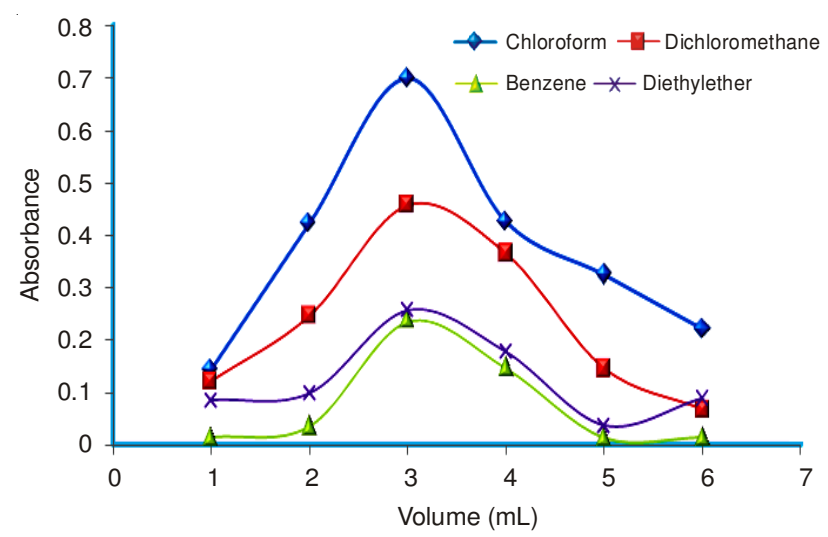

Fig. 6. Effect of different types of solvents on the extraction of trovafloxacin complex with bromothymol blue complex

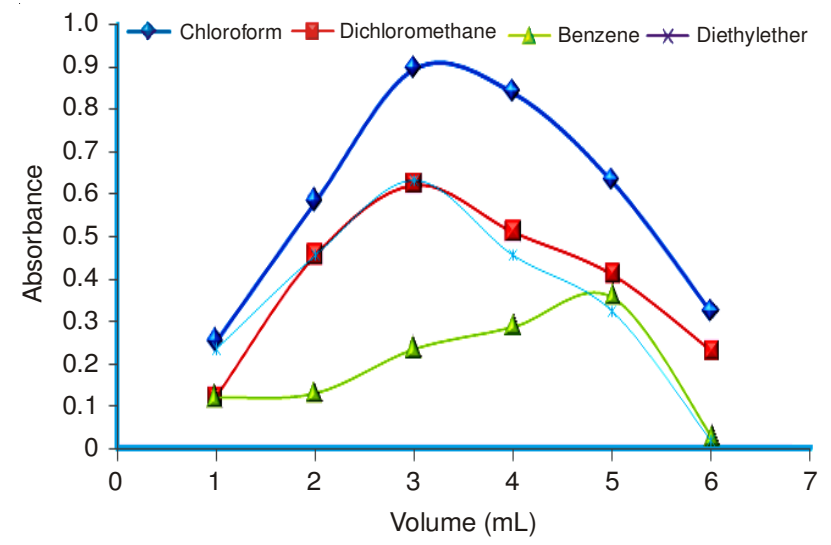

Fig. 7. Effect of different types of solvents on the extraction of trovafloxacin complex with eriochrome black-T complex

Effect of extraction time and temperature: The effect of extraction time on the ion-pair complexes was examined. TFX-BTB and TFX-EBT complexes were vigorously shaking for few minutes from 0.5 to 5.0 min with chloroform. It was found that complete colour intensity was attained after 4 and 2 min for the complexes TFX-BTB and TFX-EBT, respectively. On the other hand the effect of temperature on coloured complexes was investigated by measuring the absorbance values at different temperatures. The obtained coloured complexes were stabled up to $30{ }^{\circ} \mathrm{C}$ while at higher temperatures the investigated drug was concentrated due to the volatile nature of the chloroform. The absorbances of the coloured complexes TFXBTB and TFX-EBT were found to be stable for at least $8 \mathrm{~h}$ at room temperature $\left(25 \pm 2{ }^{\circ} \mathrm{C}\right)$.

Stoichiometric ratio of the ion-pair complexes: The stoichiometric ratio of the investigated drug and each reagent in the ion-pair complexes was tested by applying the continuous variations method (Fig. 8). Equimolar solutions $1 \times 10^{-5}$ $\mathrm{mol} \mathrm{\textrm {L } ^ { - 1 }}$ of trovafloxacin mesylate and each reagent (bromothymol blue and eriochrome black-T) were employed. The solutions were prepared as a series, in which the total volume

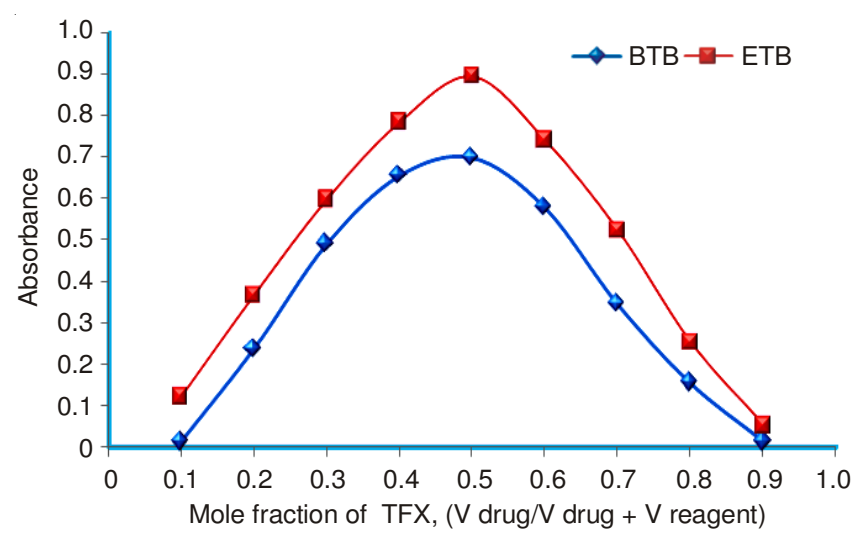

Fig. 8. Job's method of continuous variations graph for the reaction of trovafloxacin with bromothymol blue, and eriochrome black-T; $[$ Drug $]=[$ dye $]=1 \times 10^{-5} \mathrm{~mol} \mathrm{~L}^{-1}$

of the drug and reagent was kept at $10 \mathrm{~mL}$ for both bromothymol blue and eriochrome black-T. The results obtained indicated that the stoichiometric ratio 1:1 of the ion-pairs (TFX: BTB) and (TFX: EBT) were formed through the electrostatic attraction between positive protonated trovafloxacin mesylate and bromothymol blue and eriochrome black-T.

Method validation: To confirm that the analytical procedure is suitable for a specific test and intended uses, method validation was employed. In the present study method validation was carried out with respect to linearity, lower limit of detection, quantification limit, sensitivity, accuracy, precision, robustness and ruggedness according to $\mathrm{ICH}$ guidelines ${ }^{33}$.

Linearity: At optimum experimental conditions for determination of trovafloxacin mesylate the standard calibration graph of trovafloxacin mesylate was constructed and the absorbance readings were plotted against the concentrations of the investigated drug. Beer's law was obeyed over concentration ranges of 2-100 and 5-150 $\mu \mathrm{g} \mathrm{mL}^{-1}$ for TFX-BTB and TFX-EBT complexes, respectively. The linear regression equations and correlation coefficients were listed in Table-1.

Lower limit of detection and quantification: The lower limit of detection (LOD) and limit of quantification (LOQ) for the proposed methods were calculated according to ICH guide-lines ${ }^{33}$. The following equations were used:

$$
\mathrm{LOD}=3 \mathrm{~s} / \mathrm{k} \quad \mathrm{LOQ}=10 \mathrm{~s} / \mathrm{k}
$$

where $\mathrm{s}$ is the standard deviation of the response of the blank solution and $\mathrm{k}$ is the sensitivity, namely, the slope of the calibration graph. The calculated LOD were found to be 0.87 and $1.84 \mu \mathrm{g} \mathrm{mL}^{-1}$ and LOQ were found to be 2 and $5 \mu \mathrm{g} \mathrm{mL}-1$ for both methods I and II, respectively.

Robustness and ruggedness of the proposed methods: To evaluate the robustness of the proposed methods small variations of the methods variables such as concentration, volume of reagents and reaction time were done. The results obtained revealed that there is no significant difference between the results obtained by the proposed methods and those after small variations (Table-1). While, for methods ruggedness \% RSD was calculated by applying the same procedure for each method using two different instruments on different days. The results obtained were found to be 0.7 and $0.4 \%$ for TFX-BTB and TFX-EBT methods, respectively. The $\% \mathrm{RSD}$ was less than $2 \%$ which indicated that the developed methods were robust and rugged. 


\begin{tabular}{|c|c|c|c|c|c|c|c|}
\hline \multicolumn{8}{|c|}{$\begin{array}{c}\text { TABLE-1 } \\
\text { CRITICAL RESPONSE CHARACTERISTICS OF TFX-BTB AND TFX-EBT COMPLEXES }\end{array}$} \\
\hline \multicolumn{3}{|c|}{ Parameter } & \multicolumn{3}{|c|}{ TFX-BTB } & \multicolumn{2}{|c|}{ TFX-EBT } \\
\hline \multirow{2}{*}{\multicolumn{3}{|c|}{ 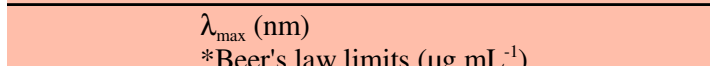 }} & \multicolumn{3}{|c|}{415} & \multicolumn{2}{|c|}{530} \\
\hline & \multicolumn{2}{|c|}{ *Beer's law limits $\left(\mu \mathrm{g} \mathrm{mL}^{-1}\right)$} & \multicolumn{3}{|c|}{$2.0-100$} & \multicolumn{2}{|c|}{$5.0-130$} \\
\hline \multicolumn{3}{|c|}{ Volume of acetate buffer (mL) } & \multicolumn{3}{|c|}{2.0} & \multicolumn{2}{|c|}{2.0} \\
\hline \multicolumn{3}{|c|}{ Volume of reagent $(\mathrm{mL})$} & \multicolumn{3}{|c|}{2.0} & \multicolumn{2}{|c|}{1.0} \\
\hline \multicolumn{3}{|c|}{ Concentration $(\mathrm{w} / \mathrm{v})$ of reagent } & \multicolumn{3}{|c|}{$0.04 \%$} & \multicolumn{2}{|c|}{$0.2 \%$} \\
\hline \multicolumn{3}{|c|}{ Extracting solvent } & & Chloroform & & Chloro & \\
\hline & Extracting time (min) & & & 4.0 & & 2. & \\
\hline & $* *$ Regression equatio & & & $Y=0.0077 x-0.0019$ & & $Y=0.0058$ & 1841 \\
\hline & Correlation coefficien & & & 0.9991 & & 0.99 & \\
\hline & $\operatorname{LOD}\left(\mu \mathrm{g} \mathrm{mL}^{-1}\right)$ & & & 0.87 & & 1.8 & \\
\hline & $\mathrm{LOQ}\left(\mu \mathrm{g} \mathrm{mL}^{-1}\right)$ & & & 2.0 & & 5. & \\
\hline & Sandell's sensitivity ( & & & 0.0043 & & 0.00 & \\
\hline & Molar absorbitivity $(\varepsilon$ & $\mathrm{mol}^{-1} \mathrm{~cm}^{-1}$ & & $2.97 \times 10^{3}$ & & $4.57 \times$ & \\
\hline & Robustness & & & $99.52 \pm 0.8$ & & 99.14 & \\
\hline & Ruggedness as \%RSD & & & $0.7 \%$ & & 0.4 & \\
\hline *Average of thr & aree experiments & & & & $* * Y=a+b x$ & & \\
\hline $\begin{array}{l}\text { Sensitivity } \\
\text { gate the validity } \\
\text { of trovafloxaci } \\
\text { dosage form. } \\
\text { sensitivity of th } \\
\text { of trovafloxaci } \\
\text { form. } \\
\text { Accuracy } \\
\text { results obtain } \\
\text { (capillary zone }\end{array}$ & $\begin{array}{l}\text { ty: Standard additio } \\
\text { ty of the proposed } \\
\text { in mesylate in pure } \\
\text { The results obtail } \\
\text { the proposed meth } \\
\text { in mesylate drug is } \\
\text { y and precision: } \\
\text { ned by the propo } \\
\text { e electrophoresis us }\end{array}$ & $\begin{array}{l}\text { thod was usec } \\
\text { ds for the det } \\
1 \text { and its phar } \\
\text { Table-2) cla } \\
\text { r routine det } \\
\text { x powder and } \\
\text { stical analys } \\
\text { and reported } \\
5 \mathrm{mmol} \mathrm{L}^{-1} \mathrm{bc}\end{array}$ & $\begin{array}{l}\text { lesti- } \\
\text { ation } \\
\text { itical } \\
\text { high } \\
\text { ation } \\
\text { sage } \\
\text { f the } \\
\text { lod }^{30} \\
\text { uffer }\end{array}$ & $\begin{array}{l}\text { and } 35 \mathrm{mmol} \mathrm{L}^{-1} \mathrm{p} \\
262 \mathrm{~nm} \text { ) using stuc } \\
\text { no significant diffe } \\
\text { accuracy and prec } \\
\text { was evaluated by d } \\
\text { trovafloxacin mes } \\
\text { evaluated through } \\
\text { a period of } 3 \text { suc } \\
\text { inter-day precisior }\end{array}$ & $\begin{array}{l}\text { osphate buff } \\
\text { nt's t-test and } \\
\text { ences betwee } \\
\text { ion, respecti } \\
\text { termination o } \\
\text { ate drug. The } \\
\text { plicate analy } \\
\text { ssive days. } \\
\text { are summariz }\end{array}$ & $\begin{array}{l}\text { at } \mathrm{pH} 8.6 \\
\text { ariance rat } \\
\text { the two me } \\
\text { ly. The int } \\
\text { nine conce } \\
\text { nter-day pr } \\
\text { s of nine co } \\
\text { e results c } \\
\text { d in Table- }\end{array}$ & $\begin{array}{l}\text { detection at } \\
\text {-test showed } \\
\text { ds regarding } \\
\text { ay precision } \\
\text { tions of pure } \\
\text { ion was also } \\
\text { ntrations for } \\
\text { tra-day and }\end{array}$ \\
\hline $\begin{array}{r}\text { DETERN } \\
\text { BR }\end{array}$ & $\begin{array}{l}\text { MINATION OF TRO } \\
\text { ROMOTHYMOL BLL }\end{array}$ & $\begin{array}{l}\text { OXACIN MES } \\
\text { JD ERIOCHRO } \\
\text { COMPARISO }\end{array}$ & $\begin{array}{l}\text { TABLE- } \\
\text { E IN PURE } \\
\text { CACK-T EX } \\
\text { H A REPOR }\end{array}$ & $\begin{array}{l}\text { E-2 } \\
\text { E FORM AND PHAR } \\
\text { XTRACTIVE SPECT } \\
\text { RTED METHOD [Re }\end{array}$ & $\begin{array}{l}\text { [ACEUTICAL I } \\
\text { OPHOTOMET] } \\
30]\end{array}$ & $\begin{array}{l}\text { OSAGE FOR } \\
\text { IC METHOD }\end{array}$ & JSING \\
\hline & & TFX-BTB & & & TFX-EBT & & \\
\hline & $\begin{array}{c}\text { Taken } \\
\left(\mu \mathrm{g} \mathrm{mL}^{-1}\right)\end{array}$ & $\begin{array}{c}\text { Found } \\
\left(\mu \mathrm{g} \mathrm{mL} L^{-1}\right)\end{array}$ & $\begin{array}{c}\text { Recovery } \\
(\%)\end{array}$ & $\begin{array}{c}\text { Taken } \\
\left(\mu \mathrm{g} \mathrm{mL} \mathrm{mL}^{-1}\right)\end{array}$ & $\begin{array}{c}\text { Found } \\
\left(\mu \mathrm{g} \mathrm{mL} L^{-1}\right)\end{array}$ & $\begin{array}{l}\text { Recovery } \\
(\%)\end{array}$ & \\
\hline & 2 & 1.95 & 97.5 & 5.0 & 4.89 & 97.8 & \\
\hline & 10 & 9.98 & 99.8 & 10.0 & 10.01 & 100.1 & \\
\hline & 20 & 19.86 & 99.3 & 50.0 & 49.74 & 99.4 & \\
\hline Pure form & 40 & 39.75 & 99.4 & 80.0 & 80.00 & 100.0 & $\begin{array}{l}\text { Reported } \\
\text { method }^{30}\end{array}$ \\
\hline & 60 & 59.99 & 99.9 & 100.0 & 99.84 & 99.8 & \\
\hline & 80 & 79.87 & 99.8 & 120.0 & 118.98 & 99.2 & \\
\hline & 100 & 99.98 & 99.9 & 130.0 & 130.00 & 100.0 & \\
\hline Mean \pm SD & & $99.4 \pm 0.9$ & & & $99.5 \pm 0.8$ & & $99.0 \pm 1.3$ \\
\hline $\mathrm{n}$ & & 7 & & & 7 & & 6 \\
\hline Variance & & 0.81 & & & 0.64 & & 1.69 \\
\hline$* \% \mathrm{SE}$ & & 0.34 & & & 0.30 & & 0.53 \\
\hline$\%$ RSD & & 0.91 & & & 0.80 & & 1.3 \\
\hline t-test & & $0.64(2.20)^{* *}$ & & & $0.82(2.20)^{* *}$ & & \\
\hline F-test & & $2.08(4.95)^{* *}$ & & & $2.64(4.95)^{* *}$ & & \\
\hline Trovan ${ }^{\circledR}$ & 2 & 1.96 & 98.0 & 5.0 & 4.99 & 99.8 & \\
\hline$(100$ & 10 & 10.00 & 100.0 & 10.0 & 9.89 & 98.9 & \\
\hline $\mathrm{mg} /$ tablet & 20 & 19.78 & 98.9 & 50.0 & 49.77 & 99.5 & \\
\hline & 40 & 39.99 & 99.9 & 80.0 & 80.00 & 100.0 & \\
\hline & 60 & 59.95 & 99.9 & 100.0 & 99.93 & 99.9 & \\
\hline & 80 & 80.00 & 100.0 & 120.0 & 119.89 & 99.9 & \\
\hline & 100 & 98.95 & 98.9 & 130.0 & 128.69 & 98.9 & \\
\hline Mean \pm SD & & $99.4 \pm 0.8$ & & & $99.6 \pm 0.5$ & & $99.5 \pm 0.6$ \\
\hline $\mathrm{n}$ & & 7 & & & 7 & & 6 \\
\hline Variance & & 0.64 & & & 0.25 & & 0.36 \\
\hline$* \% \mathrm{SE}$ & & 0.30 & & & 0.19 & & 0.24 \\
\hline$\%$ RSD & & 0.80 & & & 0.50 & & 0.60 \\
\hline t-test & & $0.26(2.20)^{* *}$ & & & $0.33(2.20)^{* *}$ & & \\
\hline F-test & & $1.78(4.95) * *$ & & & $1.44(4.95)^{* *}$ & & \\
\hline
\end{tabular}




\begin{tabular}{|c|c|c|c|c|c|c|}
\hline \multicolumn{7}{|c|}{$\begin{array}{c}\text { TABLE-3 } \\
\text { VALIDATION OF THE PROPOSED METHODS FOR DETERMI }\end{array}$} \\
\hline & \multicolumn{3}{|c|}{ TFX-BTB } & \multicolumn{3}{|c|}{ TFX-EBT } \\
\hline & $\begin{array}{c}\text { Taken } \\
\left(\mu \mathrm{g} \mathrm{mL} L^{-1}\right) \\
\end{array}$ & $\begin{array}{c}\text { Found } \\
\left(\mu \mathrm{gL} \mathrm{m}^{-1}\right)\end{array}$ & $\begin{array}{l}\text { Recovery } \\
\%\end{array}$ & $\begin{array}{c}\text { Taken } \\
\left(\mu \mathrm{g} \mathrm{mL} L^{-1}\right)\end{array}$ & $\begin{array}{c}\text { Found } \\
\left(\mu \mathrm{g} \mathrm{mL}^{-1}\right)\end{array}$ & $\begin{array}{c}\text { Recovery } \\
\%\end{array}$ \\
\hline \multirow{9}{*}{$\begin{array}{l}\text { Intra-day } \\
\text { precision }\end{array}$} & 2.0 & 1.96 & 98.0 & 5.0 & 4.98 & 99.6 \\
\hline & 4.0 & 3.99 & 99.8 & 10.0 & 9.92 & 99.2 \\
\hline & 6.0 & 5.97 & 99.5 & 20.0 & 19.93 & 99.7 \\
\hline & 8.0 & 7.82 & 97.8 & 40.0 & 39.99 & 99.9 \\
\hline & 10.0 & 9.92 & 99.2 & 60.0 & 59.89 & 99.8 \\
\hline & 20.0 & 20.0 & 100.0 & 80.0 & 79.91 & 99.9 \\
\hline & 50.0 & 49.89 & 99.8 & 100.0 & 99.96 & 99.9 \\
\hline & 80.0 & 80.00 & 100.0 & 120.0 & 119.87 & 99.8 \\
\hline & 100.0 & 99.98 & 99.9 & 130.0 & 130.00 & 100.0 \\
\hline Mean \pm SD & \multicolumn{3}{|c|}{$99.3 \pm 0.9$} & \multicolumn{3}{|c|}{$99.8 \pm 0.2$} \\
\hline $\mathrm{n}$ & \multicolumn{3}{|c|}{9} & \multicolumn{3}{|c|}{9} \\
\hline Variance & \multicolumn{3}{|c|}{0.81} & \multicolumn{3}{|c|}{0.04} \\
\hline$* \% \mathrm{SE}$ & \multicolumn{3}{|c|}{0.30} & \multicolumn{3}{|c|}{0.07} \\
\hline$\%$ RSD & \multicolumn{3}{|c|}{0.90} & \multicolumn{3}{|c|}{0.20} \\
\hline \multirow{9}{*}{$\begin{array}{l}\text { Inter-day } \\
\text { precision }\end{array}$} & 2.0 & 2.00 & 100.0 & 5.0 & 4.98 & 99.6 \\
\hline & 4.0 & 3.95 & 98.8 & 10.0 & 9.83 & 98.2 \\
\hline & 6.0 & 5.97 & 99.5 & 20.0 & 20.00 & 100.0 \\
\hline & 8.0 & 7.88 & 98.5 & 40.0 & 39.74 & 99.4 \\
\hline & 10.0 & 9.99 & 99.9 & 60.0 & 59.50 & 99.2 \\
\hline & 20.0 & 20.00 & 100.0 & 80.0 & 79.72 & 99.6 \\
\hline & 50.0 & 49.87 & 99.7 & 100.0 & 99.90 & 99.9 \\
\hline & 80.0 & 80.00 & 100.0 & 120.0 & 119.92 & 99.9 \\
\hline & 100.0 & 99.58 & 99.6 & 130.0 & 129.82 & 99.8 \\
\hline Mean \pm SD & \multicolumn{3}{|c|}{$99.6 \pm 0.6$} & \multicolumn{3}{|c|}{$99.5 \pm 0.5$} \\
\hline $\mathrm{n}$ & \multicolumn{3}{|c|}{9} & \multicolumn{3}{|c|}{9} \\
\hline Variance & \multicolumn{3}{|c|}{0.36} & \multicolumn{3}{|c|}{0.25} \\
\hline$* \% \mathrm{SE}$ & \multicolumn{3}{|c|}{0.20} & \multicolumn{3}{|c|}{0.16} \\
\hline$\%$ RSD & \multicolumn{3}{|c|}{0.60} & \multicolumn{3}{|c|}{0.50} \\
\hline
\end{tabular}

\begin{tabular}{|c|c|c|c|c|c|c|c|}
\hline \multicolumn{8}{|c|}{$\begin{array}{l}\text { TABLE-4 } \\
\text { DETERMINATION OF TROVAFLOXACIN MESYLATE IN HUMAN URINE AND SERUM USING BROMOTHYMOL BLUE } \\
\text { AND ERIOCHROME BLACK-T EXTRACTIVE SPECTROPHOTOMETRIC METHODS IN } \\
\text { COMPARISON WITH A REPORTED METHOD [REF. 30] }\end{array}$} \\
\hline & \multicolumn{3}{|c|}{ TFX-BTB } & \multicolumn{3}{|c|}{ TFX-EBT } & \\
\hline & $\begin{array}{c}\text { Taken } \\
\left(\mu \mathrm{g} \mathrm{mL}^{-1}\right)\end{array}$ & $\begin{array}{c}\text { Found } \\
\left(\mu \mathrm{g} \mathrm{mL}^{-1}\right)\end{array}$ & $\begin{array}{c}\text { Recovery } \\
(\%)\end{array}$ & $\begin{array}{c}\text { Taken } \\
\left(\mu \mathrm{g} \mathrm{mL}^{-1}\right)\end{array}$ & $\begin{array}{c}\text { Found } \\
\left(\mu \mathrm{g} \mathrm{mL}^{-1}\right)\end{array}$ & $\begin{array}{c}\text { Recovery } \\
(\%)\end{array}$ & \\
\hline Urine sample & $\begin{array}{c}2.0 \\
20.0 \\
40.0 \\
60.0 \\
80.0 \\
100.0 \\
\end{array}$ & $\begin{array}{c}1.98 \\
19.72 \\
39.65 \\
59.99 \\
79.93 \\
98.92 \\
\end{array}$ & $\begin{array}{l}99.0 \\
98.6 \\
99.1 \\
99.9 \\
99.9 \\
98.9 \\
\end{array}$ & $\begin{array}{c}5.0 \\
50.0 \\
80.0 \\
100.0 \\
120.0 \\
130.0 \\
\end{array}$ & $\begin{array}{c}4.85 \\
49.56 \\
79.99 \\
99.69 \\
119.98 \\
129.92 \\
\end{array}$ & $\begin{array}{l}97.0 \\
99.1 \\
99.9 \\
99.7 \\
99.9 \\
99.9 \\
\end{array}$ & $\begin{array}{l}\text { Reported } \\
\text { method }^{30}\end{array}$ \\
\hline $\begin{array}{l}\text { Mean } \pm \text { SD } \\
\mathrm{n} \\
\text { Variance } \\
\% \text { SE } \\
\% \text { RSD } \\
\text { t-test } \\
\text { F-test }\end{array}$ & & $\begin{array}{c}99.2 \pm 0.5 \\
6 \\
0.25 \\
0.20 \\
0.50 \\
0.73(2.23)^{*} \\
3.24(5.05)^{*}\end{array}$ & & & $\begin{array}{c}99.3 \pm 1.1 \\
6 \\
1.21 \\
0.44 \\
1.11 \\
0.35(2.20)^{*} \\
1.49(5.05)^{*}\end{array}$ & & $\begin{array}{c}99.5 \pm 0.9 \\
6 \\
0.81 \\
0.36 \\
0.90\end{array}$ \\
\hline Serum sample & $\begin{array}{c}2.0 \\
20.0 \\
40.0 \\
60.0 \\
80.0 \\
100.0 \\
\end{array}$ & $\begin{array}{c}1.99 \\
19.65 \\
39.86 \\
59.63 \\
80.00 \\
99.98 \\
\end{array}$ & $\begin{array}{c}99.5 \\
98.3 \\
99.7 \\
99.4 \\
100.0 \\
99.9 \\
\end{array}$ & $\begin{array}{c}5.0 \\
50.0 \\
80.0 \\
100.0 \\
120.0 \\
130.0 \\
\end{array}$ & $\begin{array}{c}4.86 \\
49.50 \\
79.96 \\
99.99 \\
119.89 \\
129.63 \\
\end{array}$ & $\begin{array}{l}97.2 \\
99.0 \\
99.9 \\
99.9 \\
99.9 \\
99.7 \\
\end{array}$ & \\
\hline $\begin{array}{l}\text { Mean } \pm \text { SD } \\
\mathrm{n} \\
\text { Variance } \\
\% \text { SE } \\
\% \text { RSD } \\
\text { t-test } \\
\text { F-test } \\
\end{array}$ & & $\begin{array}{c}99.5 \pm 0.6 \\
6 \\
0.36 \\
0.24 \\
0.60 \\
0.54(2.23)^{*} \\
1.36(5.05)^{*}\end{array}$ & & & $\begin{array}{c}99.2 \pm 1.1 \\
7 \\
1.21 \\
0.44 \\
1.10 \\
0.19(2.23)^{*} \\
2.46(5.05)^{*} \\
\end{array}$ & & $\begin{array}{c}99.3 \pm 0.7 \\
6 \\
0.49 \\
0.28 \\
0.70\end{array}$ \\
\hline
\end{tabular}

*Fig. in parentheses are the tabulated t- and F-values at confidence limit $95 \%$ [Ref. 34] 
Determination of trovafloxacin mesylate in human urine and serum: Due to the high sensitivity of the developed methods, we tried to check their applicability to determine trovafloxacin mesylate in biological fluids such as human urine and serum. The obtained results (Table-4) indicated good accuracy and precision as the recovery values in human urine were $99.2 \pm 0.5$ and $99.3 \pm 1.1$ for methods I and II, respectively. While, for human serum recovery values were $99.5 \pm$ 0.6 and $99.2 \pm 1.1$ for methods I and II, respectively, with $\%$ RSD of 0.5 and $1.1,0.6$ and $1.1 \%$ for human urine and serum for methods I and II, respectively.

\section{Conclusion}

New sensitive and selective extractive spectrophotometric methods for the determination of trovafloxacin mesylate were developed. The developed methods were based on the formation of extractable coloured ion-pair complexes from the reaction of trovafloxacin mesylate with bromothymol blue and eriochrome black- $\mathrm{T}$ in acidic medium. It can be evident that beside their sensitivity and simplicity both methods can be employed for determination of trovafloxacin mesylate without elaborated treatment of the samples. No critical reagents or expensive instruments are required. The accuracy and reproducibility of the proposed methods introduce great value and encourage the analytical application of trovafloxacin in pure bulk drug, its pharmaceutical dosage forms and biological fluids.

\section{ACKNOWLEDGEMENTS}

This research project was supported by a grant from the "Research Center of the Female Scientific and Medical Colleges", Deanship of scientific research, King Saud University.

\section{REFERENCES}

1. R.W. Sabnis, Handbook of Acid-Base Indicators, CRC Press, ISBN: 0-8493-8218-1 (2007).

2. N. Alizadeh and Z. Rezakhani, J. Chil. Chem. Soc., 57, 1104 (2012).

3. K.C. Ramesh, B.G. Gowda, M.B. Melwanki, J. Seetharamappa and J. Keshavayya, Anal. Sci., 17, 1101 (2001).

4. N. Rahman and S.N. Hejaz-Azmi, J. Pharm. Biomed. Anal., 24, 33 (2000).

5. H.A. Omara and A.S. Amin, J. Saud. Chem. Soc., 16, 75 (2012).

6. B. Patel, J. Patel, H. Singh and B. Patel, Int. J. Pharm. Sci. Drug Res., 3, 197 (2011).
7. Y. Duneetha and N.V.S. Naidu, Int. J. Sci. Res., 3, 25 (2014).

8. R.V. Rele, P.D. Desal and S.A. Sawant, Int. J. Chem. Sci., 8, 22 (2010).

9. A.K. Mahmood, J. Al-Nah. Univ., 16, 1 (2013).

10. M. Ravi, T.L.G. Veeraiah and C.V.R. Reddy, Orient. J. Chem., 30, 723 (2014).

11. O. Cakir, E. Coskun, E. Bicer and S. Cakir, Turk. J. Chem., 25, 33 (2001).

12. A. Young and T.R. Sweet, Anal. Chem., 27, 418 (1955).

13. S.B. Dabhade and S.P. Sangal, Microchem. J., 13, 193 (1968).

14. H. Zhou, X. Wu, F. Meng, J. Yang and M. Wang, Spectrochim. Acta A, 78, 681 (2011).

15. N.A. Alarfaj, R.A. Ammar and M.F. El-Tohammy, Asian J. Chem., 26, 2992 (2014).

16. R.A. Sayed, W.S. Hassan, M.Y. El-Mammli and A.A. Shalaby, Orient. J. Chem., 28, 639 (2012).

17. N. Rahman, N. Ahmad Khan and S.N. Hejaz Azmi, IL Farmaco, 59, 47 (2004).

18. G. Tuljarani, D. Gowrisankar, P. Kadgapathi, R. Suthakaran and B. Satyanarayana, Int. J. Pharm. Tech. Res., 2, 1787 (2010).

19. H. Yao, Y. Sun, X. Lin, Y. Tang, A. Liu, G. Li, W. Li and S. Zhang, Anal. Sci., 23, 677 (2007).

20. National Committee for Clinical Laboratory Standards, Methods for Dilution Antimicrobial Susceptibility Tests for Bacteria that Grow Aerobically "C Fourth Edition; Approved Standard, NCCLS Document M7-A4, Vol. 17, No. 2, NCCLS, Wayne, PA, January, (1997).

21. A.H. Mahmood, G.A. Medley, J.E. Grice, X. Liu and M.S. Roberts, J. Pharm. Biomed. Anal., 62, 220 (2012).

22. J. Sousa, G. Alves, G. Campos, A. Fortuna and A. Falcão, J. Chromatrogr. B, 930, 104 (2013).

23. H. Liang, M.B. Kays and K.M. Sowinski, J. Chromatogr. B Analyt. Technol. Biomed. Life Sci., 772, 53 (2002).

24. R. Teng, T.G. Tensfeldt, T.E. Liston and G. Foulds, J. Chromatogr. B Biomed. Appl., 675, 53 (1996).

25. K. Borner, H. Hartwig and H. Lode, J. Chromatogr. A, 846, 175 (1999).

26. J.A. Ocana, M. Callejon and F.J. Barragan, Eur. J. Pharm. Sci., 13, 297 (2001).

27. J.L. Vílchez, J. Taoufiki, L. Araujo and A. Navalón, J. Pharm. Biomed. Anal., 31, 465 (2003).

28. J.L. Vilchez, J. Taoufiki, O. Ballesteros and A.M. Navalon, Mikrochim. Acta, 150, 247 (2005).

29. J.L. Vílchez, J. Taoufiki and A. Navalón, Anal. Lett., 35, 257 (2002).

30. J.L. Vilchez, L. Araujo, A. Prieto and A. Navalon, J. Chromatogr. A, 56, 351 (2002).

31. A.M. El-Didamony and M.A. Moustafa, Arab. J. Chem., 3, 265 (2010).

32. A.F. Al-Ghamdi, M.M. Hefnawy, A.A. Al-Majed and F.F. Belal, Chem. Cent. J., 6, 15 (2012).

33. ICH Technical Requirements for Registration of Pharmaceuticals for Human Use, Complementary Guidelines on Methodology, Washington, DC, vol. 13 (1996).

34. J.C. Miller and J.N. Miller, Statistics for Analytical Chemistry, Ellis Horwood-Prentice Hall, Chichester, edn 3 (1993). 